\title{
PHYSIOLOGY OF THE EYE
}




\section{PHYSIOLOGY OF THE EYE}

\section{Hugh Davson DSc (Lond)}

Visiting Professor of Physiology, St. Thomas's Hospital and Southampton University Medical Schools, Honorary Research Fellow, King's College, London and Fellow, University College, London

Fifth Edition 
This edition (C) Hugh Davson 1990

Softcover reprint of the hardcover 5th edition 1990 978-0-333-45860-0

All rights reserved. No reproduction, copy or transmission of this publication may be made without written permission.

No paragraph of this publication may be reproduced, copied or transmitted save with written permission or in accordance with the provisions of the Copyright Act 1956 (as amended), or under the terms of any licence permitting limited copying issued by the Copyright Licensing Agency, 33-4 Alfred Place, London WC1E 7DP.

Any person who does any unauthorised act in relation to this publication may be liable to criminal prosecution and civil claims for damages.

First edition 1949

Second edition 1963

Third edition 1972

Fourth edition published by Churchill Livingstone 1980

Fifth edition 1990

Published by

THE MACMILLAN PRESS LTD

Houndmills, Basingstoke, Hampshire RG21 2XS

and London

Companies and representatives

throughout the world

Typeset by Macmillan India Ltd., Bangalore 25

Transferred to digital print $\mathbf{2 0 0 7}$

British Library Cataloguing in Publication Data

Davson, Hugh, 1909-

Physiology of the eye. -5 th ed.

1. Man. Eyes. Physiology

I. Title

612'.84

ISBN 978-1-349-09999-3

ISBN 978-1-349-09997-9 (eBook)

DOI 10.1007/978-1-349-09997-9

Logging, pulping and manufacturing processes are expected to conform to the environmental regulations of the country of origin. 
To my fellow Academician

Professor Ljubiša Rakić 


\section{CONTENTS}

Preface to the Fifth Edition

xi

Acknowledgements

SECTION 1 THE VEGETATIVE PHYSIOLOGY AND BIOCHEMISTRY OF THE EYE 1

1 The Aqueous Humour and the Intraocular Pressure 3

Anatomical relationships $\quad 7$

$\begin{array}{lr}\text { Physiology of the vascular system } & 15\end{array}$

The aqueous humour $\quad 18$

$\begin{array}{ll}\text { The blood-aqueous barrier } & 22\end{array}$

$\begin{array}{ll}\text { The blood-vitreous or blood-retinal barrier } & 24\end{array}$

$\begin{array}{lr}\text { Anterior and posterior chamber analysis } & 26\end{array}$

The morphology of the barriers $\quad 28$

$\begin{array}{ll}\text { Secretion of aqueous humour } & 31\end{array}$

Electrical characteristics of retinal pigment epithelium $\quad 36$

$\begin{array}{ll}\text { Active transport out of the eye } & 37\end{array}$

$\begin{array}{ll}\text { Some factors affecting rate of secretion } & 38\end{array}$

$\begin{array}{lr}\text { Intraocular pressure } & 39\end{array}$

$\begin{array}{lr}\text { The drainage of aqueous humour } & 40\end{array}$

$\begin{array}{lr}\text { The intraocular pressure } & 48\end{array}$

$\begin{array}{ll}\text { Effects of the nervous system on secretion and pressure } & 65\end{array}$

2 The Vitreous Body $\quad 96$

3 The Cornea $r \begin{array}{lr}105 \\ \text { Structurea }\end{array}$

$\begin{array}{lr}\text { Structure } & 105\end{array}$

$\begin{array}{lr}\text { Chemistry } & 108\end{array}$

$\begin{array}{lr}\text { Hydration and transparency } & 110\end{array}$

$\begin{array}{lr}\text { Permeability } & 118\end{array}$

$\begin{array}{lr}\text { Transparency of the cornea } & 122\end{array}$

$\begin{array}{lr}\text { Metabolism } & 122\end{array}$

$\begin{array}{lr}\text { Repair of damage } & 124\end{array}$

$\begin{array}{lr}\text { Corneal vascularization } & 130\end{array}$

4 The Lens $r$\begin{tabular}{l}
139 \\
\hline
\end{tabular}

$\begin{array}{ll}\text { Development and structure } & 139\end{array}$

$\begin{array}{ll}\text { Transparency } & 145\end{array}$

The lens as a functional unit $\quad 145$

Metabolism 153

$\begin{array}{ll}\text { The proteins } & 155\end{array}$

$\begin{array}{ll}\text { Cataract } & 173\end{array}$ 
$\begin{array}{llr}\text { SECTION } 2 \text { THE MECHANISM OF VISION } & 203\end{array}$

$5 \quad$ Retinal Structure and Organization $\quad 205$

$\begin{array}{lr}\text { Structure } & 205\end{array}$

6 Measurement of the Stimulus and Dioptrics of the Human Eye 211

$\begin{array}{ll}\text { Photometry } & 211\end{array}$

$\begin{array}{ll}\text { Dioptrics } & 215\end{array}$

7 Some General Aspects of Vision $\quad 219$

$\begin{array}{ll}\text { The light sense } & 219\end{array}$

$\begin{array}{ll}\text { The colour sense } & 221\end{array}$

Form $\quad 225$

$\begin{array}{ll}\text { Induction } & 226\end{array}$

$8 \quad$ Photochemical Aspects of Vision 230

Ultrastructure of the rods $\quad 230$

Turnover of disks $\quad 234$

Ultrastructure of the cones $\quad 236$

Extraction and characterization of photopigment $\quad 238$

Synthesis and transport to outer segments $\quad 242$

The retinal-opsin link $\quad 243$

Intermediate stages in breakdown to retinal and opsin $\quad 244$

The nature of the changes $\quad 246$

Linkage of retinal $\quad 249$

$\begin{array}{ll}\text { Regeneration of rhodopsin } & 250\end{array}$

$\begin{array}{ll}\text { Transport of retinoids } & 252\end{array}$

Comparative physiology of the pigments $\quad 254$

9 Dark Adaptation and the Minimum Visual Stimulus 264

$\begin{array}{ll}\text { The dark-adaptation curve } & 264\end{array}$

$\begin{array}{ll}\text { Adaptation studies on single receptors } & 267\end{array}$

$\begin{array}{ll}\text { Some theoretical considerations } & 270\end{array}$

$\begin{array}{ll}\text { The absolute threshold } & 271\end{array}$

$\begin{array}{ll}\text { Spatial and temporal summation } & 274\end{array}$

10 Electrophysiology of the Retina: Response to Stimulation and the Transduction Process 279

$\begin{array}{ll}\text { The sensory message } & 279\end{array}$

$\begin{array}{lr}\text { The invertebrate eye } & 279\end{array}$

$\begin{array}{lr}\text { Vertebrate responses } & 282\end{array}$

11 Electrophysiology of the Retina: Further Studies on Cold-blooded Retina 305

$\begin{array}{ll}\text { The electroretinogram } & 313\end{array}$

12 Electrophysiology of the Retina: Further Aspects $\quad 325$

$\begin{array}{ll}\text { Quantitative aspects of centre-surround organization } & 325\end{array}$

$\begin{array}{ll}\text { Classification of ganglion receptive field types } & 326\end{array}$

$\begin{array}{ll}\text { Some morphological correlates } & 334\end{array}$

$\begin{array}{ll}\text { Synaptic relationships and neuronal circuitry } & 336\end{array}$

Transmitters in the retina $\quad 343$

$\begin{array}{ll}\text { Neuronal circuitry } & 352\end{array}$

13 Flicker $\quad 362$

$\begin{array}{ll}\text { Critical fusion frequency } & 362\end{array}$

The ERG and the interpretation of flicker $\quad 363$ 
Ganglion cell discharges $\quad 365$

The visually evoked response (VER)

$\begin{array}{ll}\text { Effect of dark-adaptation } & 366\end{array}$

$\begin{array}{ll}\text { Size of patch and the Granit-Harper law } & 368\end{array}$

$\begin{array}{ll}\text { Sinusoidal wave-form } & 368\end{array}$

14 Visual Acuity $\quad 373$

$\begin{array}{ll}\text { Central and peripheral viewing } & 373\end{array}$

$\begin{array}{ll}\text { Effects of luminance of test-object and adaptation } & 373\end{array}$

$\begin{array}{ll}\text { Normal visual acuity } & 374\end{array}$

15 Wavelength Discrimination and the Theory of Colour Vision 395

$\begin{array}{ll}\text { The Purkinje phenomenon } & 395\end{array}$

$\begin{array}{ll}\text { Wavelength discrimination } & 398\end{array}$

$\begin{array}{lr}\text { The Young-Helmholtz theory } & 399\end{array}$

$\begin{array}{lr}\text { Colour-defects } & 402\end{array}$

$\begin{array}{ll}\text { Absorption spectra of receptors } & 407\end{array}$

$\begin{array}{lr}\text { Fish pigments } & 409\end{array}$

$\begin{array}{lr}\text { Evolutionary significance } & 409\end{array}$

$\begin{array}{ll}\text { Electrophysiology of wavelength discrimination } & 409\end{array}$

16 The Stiles-Crawford Effect, Adaptation and Photopic Sensitivity Curves 423

$\begin{array}{ll}\text { Directional sensitivity of the retina } & 423\end{array}$

$\begin{array}{ll}\text { Adaptation and interaction of light stimuli } & 425\end{array}$

$\begin{array}{ll}\text { Temporal aspects } & 427\end{array}$

Spatial effects $\quad 432$

$\begin{array}{ll}\text { Retinal electrophysiology and adaptation } & 437\end{array}$

$\begin{array}{lr}\text { Adaptation and the colour sense } & 440\end{array}$

$\begin{array}{ll}\text { Photopic sensitivity curves } & 441\end{array}$

Mesopic sensitivity curves $\quad 442$

$\begin{array}{llr}\text { SECTION } 3 & \text { VISUAL PERCEPTION }\end{array}$

17 Visual Perception: Introduction $\quad 449$

$\begin{array}{lr}\text { Higher integrative activity } & 449\end{array}$

$\begin{array}{lr}\text { Monocular perception } & 452\end{array}$

$\begin{array}{ll}\text { Binocular perception } & 462\end{array}$

$\begin{array}{ll}\text { Stereoscopic depth perception } & 465\end{array}$

$\begin{array}{ll}\text { Further aspects of binocular vision } & 476\end{array}$

$\begin{array}{ll}\text { The perception of motion } & 481\end{array}$

18 Neurophysiology of Perception: The Higher Visual Pathways 486

The primary visual pathway to the cerebral cortex 4486

$\begin{array}{ll}\text { Non-geniculate targets for retinofugal input } & 487\end{array}$

$\begin{array}{ll}\text { Lateral geniculate body } & 491\end{array}$

$\begin{array}{ll}\text { Electrophysiology of the higher visual pathway } & 495\end{array}$

19 Neurophysiology of Perception: Cortical Projection $\quad 515$

$\begin{array}{ll}\text { The visual cortex } & 515\end{array}$

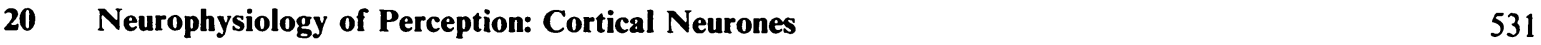

21 Neurophysiology of Perception: Spatial Analysis $\quad 558$

$\begin{array}{ll}\text { Neurophysiological basis of stereopsis } & 558\end{array}$

$\begin{array}{ll}\text { The double pathway to higher visual centres } & 569\end{array}$ 
Electrophysiological aspects of visual acuity

Colour discrimination

22 Neurophysiology of Perception: Developmental Aspects of Visual Field Characteristics

Visual deprivation

23 Neurophysiology of Perception: Non-geniculostriate Pathways and the Neurones of their Central Stations

The superior colliculi

The pulvinar

SECTION 4 THE MUSCULAR MECHANISMS

24 The Extraocular Muscles and their Actions

Binocular movements

Types of movement

Movements during steady fixation

25 Nervous Control of the Eye Movements

The muscle fibres and their innervation

Some reflexes

Vestibular and neck proprioceptive reflexes

The motor neurones

Electromyographic studies

The sensory messages

Motor neurone discharges during movements

Tensions in the eye muscles

Coordinating centres

Superior colliculus

Cortical centres

The cerebellum

Models of control

Ocular and vestibular interaction

Sphincter and dilator muscles

Nervous pathways

27 Accommodation

28 The Near Response 


\section{PREFACE TO THE FIFTH EDITION}

In writing this preface to the fifth edition of my Physiology of the Eye I am asserting the privilege of age by the indulgence in a little reminiscing. The first edition appeared some forty years ago, and was written at a time when I was teaching ocular physiology to budding ophthalmologists and orthoptists at Moorfields Hospital, and acting as examiner for the British College of Ophthalmic Opticians. The book was thus designed to be read by students in these three professional categories; in addition, of course, I hoped that students and teachers in physiology and experimental psychology would find it useful.

The first edition was, in my view, a fair presentation of the existing state of knowledge of the physiology of the eye, a field that involves several distinct disciplines, as revealed by the segregation of the book into four sections*. In making this presentation I endeavoured to be simple in my accounts so that any student with A-levels in the biological sciences would be able to follow it, but I trust that I never avoided treating the subjects in depth where there was depth; and, in looking over this first account and comparing it with the present edition, I cannot but admire the extraordinary increase in the depth of our knowledge that has resulted from the accretions of the successive decades.

Thus, the sensory electrophysiology of the visual system at the time of the first edition consisted of little more than the pioneering studies of Granit on the electroretinogram and the first single-unit studies on optic nerve fibres described by Hartline; the recording of electrical events in the actual vertebrate photoreceptor, and their interpretation, would have seemed visionary at the time. Cortical events consisted of little more than the plotting of visual fields through the analysis of the effects of lesions; and it was not until the third edition, which appeared in 1972, that I was able to begin the presentation of the studies on single units pioneered by Hubel and Wiesel. This presentation has expanded from a mere 20

\footnotetext{
* In the first three editions there was a fifth section on the Physiological Optics of the Eye. This was subsequently abandoned to make room for the rapidly expanding physiology.
}

pages in the third edition to some 80 pages in the fourth edition and 157 pages in the present volume.

In a similar way, the section covering the intraocular fluids, the cornea and crystalline lens, has expanded in keeping with the transformation of our knowledge from little more than vague speculations to sound theory, a transformation that has led to a real understanding of the physical bases for such clinical conditions as glaucoma, corneal opacification and vascularization, and cataract. In these last fields, covered by the general term 'Vegetative Physiology', my own researches on the eye were concentrated, so that their expansion, after I transferred my loyalties to the brain fluids in about 1953, has been a matter of peculiar satisfaction to me, and I like to think of myself and my younger colleagues at University College London, who continued these studies along lines that we had explored together, as pioneers in work that has led to such successful clinical applications.

In one field only, namely that of psychophysics, I find that I have not expanded my treatment in proportion to the large amount of experimental work that may largely be found described in the volumes of Vision Research. This limitation, imposed by the requirement to keep the book within the compass of a single volume, requires some apology in case I should appear to be undervaluing the contributions that this kind of experiment makes towards the understanding of higher visual functions. My excuse, then, is that Helmholtz's treatment of such visual functions as stereopsis, torsional eye movements, and the general interpretation of the visual image, remains as fundamental and as valid as it was when he published his Physiologischen Optik. It was this treatment that formed the basis of my first account in 1949; and, although I have added to it in the light of more modern psychophysical studies, such as those of Julesz on random-dot presentations, I have found little in the literature that has made me want to alter this first account in any fundamental way. $\mathbf{A}$ further reason, if not an excuse, is my own prejudice as a physiologist in favour of the direct approach; thus the validity of the Young-Helmholtz trichromatic theory, supported as it was by the psychophysical studies of Wright and Stiles, was only finally clinched by the absorptiometric and electrophysiological studies of single 
photoreceptors described by Tomita, Hodgkin, Wald and Dartnall.

Finally, in the field of the control of the eye movements, once again the psychophysical approach that led to the development of models of motor control has been heavily supplemented by electrophysiological studies of the cen- tral and peripheral neurones concerned in this control; and in this case it is of especial interest that the pioneers in both aspects are the same people, notably Robinson and his colleagues.

London, 1988
H.D. 


\section{ACKNOWLEDGEMENTS}

I should like to thank my colleague and friend, Dr Mal- ledge my indebtedness to the numerous authors and colm Segal, for valuable assistance in preparing the publishers who have granted their permission to reproillustrations for this edition. Also, I gratefully acknow- duce illustrations. 